\title{
Analisis Hukum Terhadap Anak Sebagai Korban Tindak Pidana Perdagangan Orang
}

\section{Legal Analysis of Minors as Victims Criminal act of people trafficking}

\author{
Jogi Septian Bangun Panjaitan1), Marlina2) \& Rizkan Zulyadi1) * \\ 1)Program Studi Magister Ilmu Hukum, Universitas Medan Area, Indonesia \\ 2) Program Studi Magister Ilmu Hukum, Universitas Sumatera Utara, Indonesia \\ Diterima: 08 Juli 2021; Direview: 02 Agustus 2021; Disetujui: 03 Oktober 2021 \\ *Coresponding Email: rizkanzulyadi@staff.uma.ac.id
}

\begin{abstract}
Abstrak
Tujuan penelitian ini adalah menganalisis aturan hukum perlindungan anak sebagai korban perdagangan orang, dan faktor-faktor penyebab tindak pidana perdagangan perempuan dan anak di Sumatera Utara, serta bagaimana kebijakan yang dilakukan dinas pemberdayaan perempuan dan anak di Sumatera Utara dalam mencegah dan mengatasi pelaku perdagangan orang terhadap anak. Jenis penelitian dalam penulisan ini adalah penelitian hukum normatif. Penelitian hukum normatif atau doktriner, yaitu penelitian hukum yang mempergunakan penelitian sumber data sekunder. Hasil penelitian dan pembahasan dalam penelitian ini adalah: Aturan Hukum Perlindungan Anak Sebagai Korban Perdagangan Orang adalah sebagai berikut: (a) Undang-Undang Nomor 23 Tahun 2002 tentang Perlindungan Anak; (b) Undang-Undang Republik Indonesia Nomor 21 Tahun 2007 tentang Pemberantasan Tindak Pidana Perdagangan Orang; (c) Undang-Undang No 35 Tahun 2014 Tentang Perubahan Undang-Undang No 23 Tahun 2002 Tentang Perlindungan Anak; (d) Peraturan Daerah Provinsi Sumatera Utara Nomor 3 Tahun 2014 tentang Penyelenggaraan Perlindungan Anak. Faktor-Faktor Penyebab Tindak Pidana Perdagangan Perempuan Dan Anak Di Sumatera Utara: Beberapa faktor yang menyebabkan terjadinya perdagangan anak antara lain sebagai berikut: (a) Kemiskinan; (b) Rendahnya Tingkat Pendidikan; (c) Korban Perceraian Orang Tua; (d) Pengalaman Seksual Dini; (e) Pencari Kerja. Kebijakan dalam penanggulangan tindak pidana perlindungan orang dilakukan dengan tiga cara yaitu: (a) Pencegahan Primer, (b) Pencegahan Sekunder, (c) Pencegahan Tersier.
\end{abstract}

Kata Kunci: Analisis Hukum; Anak, Korban Tindak Pidana; Perdagangan Orang.

\begin{abstract}
Point of this study is as follows: (a) What are the legal rules for the protection of children as victims of trafficking in persons, (b) What are the factors causing the crime of trafficking in women and children in North Sumatra, (c) What are the policies carried out by the women's empowerment office? and children in North Sumatra in preventing and overcoming traffickers against children. The type of research in this writing is normative legal research. Normative or doctrinal legal research, namely legal research that uses secondary data source research. The results of the research and discussion in this study are: The Legal Rules for the Protection of Children as Victims of Trafficking in Persons are as follows: (a) Law Number 23 of 2002 concerning Child Protection; (b) Law of the Republic of Indonesia Number 21 of 2007 concerning Eradication of the Crime of Trafficking in Persons; (c) Law No. 35 of 2014 concerning Amendments to Law No. 23 of 2002 concerning Child Protection; (d) North Sumatra Province Regional Regulation Number 3 of 2014 concerning the Implementation of Child Protection. Factors Causing the Crime of Trafficking in Women and Children in North Sumatra: Several factors that cause child trafficking include the following: (a) Poverty; (b) Low Education Level; (c) Victims of Parental Divorce; (d) Early Sexual Experience; (e) Job Seekers. Policies in overcoming criminal acts of protecting people are carried out in three ways, namely: (a) Primary Prevention, (b) Secondary Prevention, (c) Tertiary Prevention.
\end{abstract}

Keywords: Legal Analysis; Minors, Victims of Crime; Trafficking in Persons.

How to Cite: Panjaitan, J.S.B. Marlina, \& Zulyadi, R. (2021). Analisis Hukum Terhadap Anak Sebagai Korban Tindak Pidana Perdagangan Orang. Journal of Education, Humaniora and Social Sciences (JEHSS). 4(2): 1136-1153. 


\section{PENDAHULUAN}

Negara Republik Indonesia adalah Negara yang berdasarkan atas hukum (rechstaat) bukan berdasarkan atas kekuasaan (matchstaat), hal ini secara jelas disebutkan dalam Pasal 1 ayat (3) Undang-Undang Dasar Negara Republik Indonesia tahun 1945 yang rumusannya, Negara Indonesia adalah Negara Hukum (Undang-Undang Dasar Negara Republik Indonesia Tahun 1945. Dalam tujuan Negara Republik Indonesia tersebut, termaksud didalamnya adanya perlindungan bagi masyarakat dan ada hak-hak masyarakat yang dijamin dalam setiap aspek kehidupannya. Namun, fakta yang terjadi di masyarakat ternyata mulai berbanding terbalik dengan tujuan negara kita.

Dewasa ini, berbagai macam permasalahan hukum mulai terjadi. Pola tingkah laku manusiapun menjadi semakin menyimpang dan tidak sesuai dengan norma-norma yang berlaku dalam masyarakat yang pada akhirnya dapat berujung pada terjadinya suatu pelanggaran bahkan kejahatan. Kejahatan merupakan salah satu kenyataan dalam kehidupan bermasyarakat yang patut mendapatkan perhatian khusus. Hal tersebut disebabkan bukan saja karena jenis kejahatan yang terus berkembang dari waktu ke waktu, namun kejahatan juga telah menimbulkan keresahan yang mendalam serta mengganggu keamanan dan ketertiban dalam kehidupan bermasyarakat.

Perdagangan orang merupakan kejahatan yang serius terhadap kehidupan manusia dan kemanusiaan, mengingat kasus perdagangan orang semakin hari semakin luas dan semakin rumit (complicated) modus operandinya. Dewasa ini, perdagangan orang telah menjadi bisnis kejahatan yang paling menguntungkan dibandingkan dengan kejahatan terorganisir lainnya seperti trafficking of drug and arms. Hal ini mengingat dalam perdagangan orang, manusia diperlakukan sebagai komoditi yang bisa didaur ulang, artinya korban dieksploitasi, disiksa dan diperlakukan tidak manusiawi berulangkali untuk meningkatkan keuntungan pelaku.

Sebagai suatu kejahatan, tindak pidana perdagangan orang juga merupakan bentuk pelanggaran hak asasi manusia, karena pada kenyataannya korban dipaksa dan ditipu untuk masuk ke dalam proses perdagangan orang dan merekapun dieksploitasi secara seksual oleh para pelaku dalam rangka mewujudkan tujuannya. Paksaan menjadi buruh juga merupakan sebuah tindakan yang dilarang dalam konteks hak asasi manusia. Baik perbudakan, eksploitasi seksual atau apapun bentuk yang terkait dengan perdagangan orang, hal itu secara jelas terkait dengan pelanggaran hak asasi manusia (Marhus, 2011)

Perdagangan manusia memang bukanlah suatu hal yang baru di muka bumi ini, bahkan negara-negara yang kini dianggap sebagai negara besar pada awalnya banyak berhutang pada penduduk negara miskin dan lemah yang dibawa secara paksa untuk bekerja di perkebunan ataupun pabrik. Masalah perbudakan merupakan sejarah hitam umat manusia, yang bahkan juga telah direkam dalam kitab-kitab suci. Sejarah juga telah mencatat berbagai peperangan yang disebabkan karena isu perbudakan, misalnya yang terjadi antara Amerika Utara dan Selatan pada abad-abad lalu.

Apakah dengan masyarakat dunia yang makin beradap ini maka perbudakan menghilang, secara yuridis formal memang demikian, karena tidak satupun negara lagi yang mengakui dan mentolerir perbudakan. Akan tetapi tidak berarti bahwa fenomena ini sudah menghilang seluruhnya dari muka bumi. Komunitas internasional masih menengarai adanya kegiatan setara dalam bentuknya yang lebih modern yang kemudian dinamakan sebagai bentuk-bentuk perbudakan kontemporer (contemporary forms of slavery). Demikian seriusnya masalah ini, sehingga PBB melalui Office of The High Commissionerof Human Rights mengeluarkan Fact Sheet no. 14 dengan judul yang sama, Contemporary Forms of Slaver. Menurut Zulyadi, perilaku yang termasuk dalam kategori ini adalah: Perdagangan anak-anak; Porstitusi anak; Pornografi anak; Eksploitasi pekerja anak; Mutilasi seksual terhadap anak perempuan; Perlibatan anak dalam konflik bersenjata; Perhambaan; Perdagangan manusia; Perdagangan organ tubuh manusia; Eksploitasi untuk pelacuran; dan Sejumlah kegiatan di bawah rezim apartheid dan penjajahan (Zulyadi Rizkan , 2020) 
Seperti halnya kondisi perdagangan manusia yang terjadi di media massa maupun penelitian-penelitian yang dilakukan di lembaga pendidikan dan LSM menunjukkan bahwa sebagian besar korban perdagangan manusia adalah juga perempuan dan anak-anak. Berbagai penelitian menunjukkan bahwa perilaku tidak adil terhadap perempuan dan anak merupakan ancaman terus menerus bagi mereka perempuan di manapun di dunia, utamanya di negara-negara berkembang. Kini masalahnya semakin serius karena perdagangan perempuan dan anak juga terjadi di berbagai belahan dunia. Pada dasarnya dua masalah yang sangat berkenaan dengan perdagangan manusia khususnya perdagangan perempuan dan anak, adalah konstruksi sosial tentang perempuan dan anak, adalah konstruksi sosial tentang perempuan dan anak, dan kedua adalah masalah perekonomian khususnya dalam negara-negara berkembang (Rizkan, 2020)

Pembicaraan tentang anak dan perlindungannya tidak akan pernah berhenti sepanjang sejarah kehidupan, karena anak adalah generasi penerus bangsa dan penerus pembangunan, yaitu generasi yang dipersiapkan sebagai subjek pelaksana pembangunan yang berkelanjutan dan pemegang kendali massa depan suatu negara, tidak terkecuali indonesia. Perlindungan anak Indonesia berarti melindungi potensi sumber daya insani dan membangun manusia Indonesia seutuhnya, menuju masyarakat yang adil dan makmur, materil spiritual berdasarkan Pancasila dan UUD 1945.

Upaya-upaya perlindungan anak haruslah telah dimulai sedini mungkin, agar kelak dapat berpartisipasi secara optimal bagi pembangunan bangsa dan Negara. Dalam Pasal 2 ayat (3) dan (4) Undang-Undang Republik Indonesia Nomor 4 Tahun 1979 tentang Kesejahteraan Anak, ditentukan bahwa: Anak berhak atas pemeliharaan dan perlindungan baik semasa kandungan maupun sesudah dilahirkan. Anak berhak atas perlindungan-perlindungan lingkungan hidup yang dapat membahayakan atau menghambat pertumbuhan dan perkembangan dengan wajar. Kedua ayat tersebut memberikan dasar pemikiran bahwa perlindungan anak bermaksud untuk mengupayakan perlakuan yang benar dan adil, untuk mencapai kesejahteraan anak (Nashriana, 2018)

Sebagai individu yang belum mengalami kematangan, baik secara fisik maupun kejiwaannya, anak merupakan sesosok manusia rentan. Dikatakan demikian karena kemandirian dalam menentukan sikap, tindakan atau bahkan pilihannya, masih sangat dipengaruhi oleh lingkungan sekitarnya. Bahkan langkah peniruan/replikasi kondisi dan situasi lingkungan terdekat sang anak merupakan cerminan yang akan diadopsi dan tidak mustahil menjadi contoh yang diambil dalam nalar maupun sikap tindaknya. Inilah mengapa, setiap tindakan anak, sejatinya tidak selalu merefleksikan realitas diri, namun justru lebih condong kepada pola replikasi atas hasil tangkapan panca indera keseharian (Rustamaji, 2017)

Anak adalah bagian warga Negara yang harus dilindungi karena mereka merupakan generasi bangsa yang di masa mendatang akan melanjutkan kepemimpinan bangsa Indonesia. Setiap anak disamping wajib mendapatkan pendidikan formal seperti sekolah, juga wajib mendapatkan pendidikan moral sehingga mereka dapat tumbuh menjadi sosok yang berguna bagi bangsa dan negara. Tuntutan itu sesuai dengan ketentuan Konvensi Hak Anak (Convention on the Rights of the Child) yang diratifikasi oleh pemerintah Indonesia melalui Keputusan Presiden Nomor 36 Tahun 1990, kemudian juga dituangkan dalam Undang-Undang Nomor 4 Tahun 1979 tentang Kesejahteraan Anak dan Undang-Undang Nomor 23 Tahun 2002 tentang Perlindungan Anak dan Undang-Undang Nomor 11 Tahun 2012 tentang Sistem Peradilan Pidana Anak yang kesemuanya mengemukakan prinsip-prinsip umum perlindungan anak. Yaitu non diskriminasi, kepentingan terbaik bagi anak, kelangsungan hidup dan tumbuh kembang dan menghargai partisipasi anak (Dahlan, 2017)

Perdagangan perempuan bisa terjadi di dalam negeri maupun lintas negara. Proses terjadinya praktik perdagangan perempuan dimulai dari tempat tinggal asal perempuan. Biasanya para pelaku calo atau penyalur, terlibat dengan aparat di desa dalam praktik menjual dan memperdagangkan perempuan untuk mendapatkan keuntungan uang maupun lainnya.

Para pelaku ini umumnya berasal dari wilayah setempat dan berhubungan langsung atau tak langsung dengan agen tenaga kerja baik yang resmi maupun anggota perusahaan jasa tenaga kerja Indonesia (PJTKI) yang datang ke tempat asal perempuan yang akan dieksploitasi ke desa-desa. 
Banyak dari perempuan itu ditipu dan dijanjikan akan diberi pekerjaan yang baik dengan gaji yang lumayan oleh pelaku.

Bentuk perdagangan perempuan beragam, mulai dari pelacuran/pekerja seks, pekerja rumah tangga/pabrik yang tidak dibaya, kawin paksa/kontrak, pengemis, industri pornografi, dan penjualan organ tubuh. Perdagangan perempuan menimbulkan efek luar biasa bagi perempuan yang diperdagangkan. Mereka mendapatkan kekerasan. Perdagangan perempuan melibatkan aktor-aktor pelaku yang membuat perempuan terjerat dalam perdagangan perempuan.

Pemidanaan perdagangan manusia yang ada di dalam Kitab Undang-Undang Hukum Pidana (KUHP) hanya mengatur kejahatan perorangan sebagaimana terdapat di dalam Pasal 297 KUHP (perdagangan wanita dan perdagangan anak laki-laki), Pasal 324 (perniagaan budak). Dengan berlakunya UU Nomor 12 Tahun 2007 tentang Pemberantasan Tindak Pidana Perdagangan Orang, pasal-pasal tersebut di atas dicabut dan dinyatakan tidak berlaku.

Dalam praktik, perdagangan manusia dilakukan secara terorganisasi. Untuk itu UndangUndang Nomor 12 Tahun 2007 tentang Pemberantasan Tindak Pidana Perdagangan Orang (PTPPO) tidak hanya mengatur pelaku tindak pidana perorangan, tetapi juga yang dilakukan oleh korporasi, penyelenggara negara negara yang menyalahgunakan kekuasaan, serta kelompok yang terorganisir.

Undang-Undang PTPPO memberikan perlindungan terhadap anak dan memberikan pidana tambahan bagi pelaku yang melakukan perdagangan anak. Selain itu, terobosan hukum dalam Undang-Undang ini adalah adanya hak dari korban untuk tidak dijerat hukuman bila melakukan tindak pidana karena dipaksa oleh pelaku tindak pidana perdagangan orang misalnya menjadi wanita tuna susila atau melakukan kekerasan terhadap pelaku dalam upaya melakukan pembelaan diri (Yasin, 2014).

Korban tidak diberikan hak dasarnya sebagai manusia (seperti hak bebas bergerak, hak atas standar hidup yang layak termasuk pangan, sandang dan papan, hak atas tingkat hidup untuk kesehatan dan kesejahteraan diri). Ketika si anak yang masih dibawah umur menjadi korban suatu tindak pidana perdagangan orang maka sebagai Negara hukum, Indonesia akan menindaklanjuti perbuatan pelaku tersebut melalui jalur hukum pula. Penyelesaian dengan jalur hukum tentulah akan sangat mengkhawatirkan baik bagi orang tua maupun bangsa Indonesia sendiri, karena anak merupakan generasi penerus bangsa yang akan melanjutkan estafet kepemimpian bangsa ini. Jika anak tidak mendapatkan perlindungan khusus di kaca mata hukum, maka akan timbul tekanan baik fisik maupun psikis yang akan menghalangi tumbuh dan kembang anak tersebut.

Sudah sepatutnya aparat penegak hukum memberikan sanksi yang setimpal bagi pelaku tindak pidana perdagangan orang agar hukum benar-benar ditegakkan dan tercipta ketertiban dalam masyarakat. Namun, selain itu, aparat penegak hukum juga harus memperhatian pertimbangan-pertimbangan lain yang lebih komprehensif dalam menjatuhkan sanksi terhadap pelaku tindak pidana perdagangan orang. Karena sanksi bukan saja diharapkan memberikan efek jera terhadap pelaku tindak pidana perdagangan orang sehingga tidak mengulangi perbuatannya serta mencegah orang lain untuk melakukan tindak pidana tersebut, melainkan juga harus memperhatikan kepentingan terbaik bagi anak dibawah umur yang menjadi korban seperti tujuan dari dibentuknya Undang-Undang Nomor 35 Tahun 2014 Perubahan Atas Undang-Undang Nomor 23 Tahun 2002 Tentang Perlindungan Anak.

Dalam berbagai fenomena sosial yang terjadi dalam masyarakat, yang penting pula mendapatkan perhatian khusus adalah timbulnya kejahatan yang pelakunya tidak memandang jenis kelamin laki-laki maupun perempuan. Melihat perkembangan yang ada dalam masyarakat semakin hari menampakkan peningkatan yang telah merambah pada segi-segi perbuatan kriminal yang secara yuridis formal menyalahi ketentuan-ketentuan yang termaktub dalam Kitab UndangUndang Hukum Pidana (KUHP) maupun peraturan lain diluar KUHP.

Adapun tujuan yang terkandung dalam penulisan artikel ini adalah sebagai berikut: Untuk mengkaji dan menganalisis aturan hukum perlindungan anak sebagai korban perdagangan orang. Untuk mengkaji dan menganalisis faktor-faktor penyebab tindak pidana perdagangan perempuan 
dan anak di Sumatera Utara. Untuk mengkaji dan menganalisis kebijakan yang dilakukan dinas pemberdayaan perempuan dan anak di Sumatera Utara dalam mencegah dan mengatasi pelaku perdagangan orang terhadap anak.

\section{METODE PENELITIAN}

Kata metode penelitian terdiri dari dua kata yang mengandung pengertian yang saling berkaitan, yaitu metode dan penelitian. Pembagian kedua kata tersebut timbul akibat pengertian ilmu itu sendiri dapat dipahami dari dua sudut pandang, yaitu pengertian ilmu sebagai proses atau aktivitas manusia dan pengertian ilmu sebagai suatu metode. Metode dapat diartikan sebagai prosedur atau cara untuk mengetahui atau menjalankan sesuatu melalui langkah-langkah yang sistematik. Metode penelitian merupakan suatu cara yang sistematis dalam melakukan sebuah penelitian (Elisabeth, 2018)

Metode penelitian yang digunakan dalam penyusunan tesis ini dapat menggambarkan faktafakta yang timbul dari masalah-masalah yang peneliti teliti yang kemudian akan dianalisis sebagai berikut: Jenis penelitian dalam penulisan ini adalah penelitian hukum normatif. Penelitian hukum normatif atau doktriner, yaitu penelitian hukum yang mempergunakan penelitian sumber data sekunder. Jika Penelitian menggunakan penelitian hukum normatif atau doktriner yang juga disebut sebagai penelitian perpustakaan atau studi dokumen, karena lebih banyak dilakukan terhadap data yang bersifat sekunder yang ada di perpustakaan. Pada penelitian normatif data sekunder sebagai sumber/bahan informasi dapat merupakan bahan hukum primer, bahan hukum sekunder dan bahan hukum tersier.

Ilmu hukum normatif merupakan problem solving. Artinya ia merupakan analisis ilmiah tentang bagaimana memecahkan atau menguraikan berbagai problem hukum. Aktivitas ini menghasilkan argumentasi baru. Di dalam melaksanakan aktivitas ini, ilmu hukum memerlukan legal sources (bahan hukum) yaitu bahan-bahan hukum, misalnya peraturan perundangundangan, putusan hukum (Gede, 2018).

Pendekatan adalah cara pandang peneliti dalam memilih spektrum ruang bahasan yang diharap mampu memberi kejelasan uraian dari suatu substansi karya ilmiah (Diantha, 2019) Metode pendekatan yang akan diterapkan dalam penelitian hukum yang akan dilakukan oleh peneliti. Dapat memakai metode pendekatan Normatif (Legal Research), antara lain pendekatan Undang-Undang (Statute Approach), metode pendekatan kasus (Case Approach), pendekatan historis (Historical Approach), pendekatan komperatif (Comparative Approach), pendekatan konseptual (Conseptual Approach). Jika metode pendekatan yang dipergunakan dalam penelitian adalah metode pendekatan normatif, yang secara deduktif, dimulai analisis terhadap pasal-pasal yang mengatur hal-hal yang menjadi permasalahan di atas, metode pendekatan ini digunakan dengan mengingat permasalahan yang diteliti berdasarkan pada peraturan-peraturan perundangundangan yaitu hubungan peraturan satu dengan peraturan lain serta kaitannya dengan penerapannya dalam praktek (Ediwarman, 2014).

Pendekatan adalah cara pandang peneliti dalam memilih spektrum ruang bahasan yang diharap mampu memberi kejelasan uraian dari suatu substansi karya ilmiah (Diantha, 2019). Metode pendekatan yang akan diterapkan dalam penelitian hukum yang akan dilakukan oleh peneliti. Dapat memakai metode pendekatan Normatif (Legal Research), antara lain pendekatan Undang-Undang (Statute Approach), metode pendekatan kasus (Case Approach), pendekatan historis (Historical Approach), pendekatan komperatif (Comparative Approach), pendekatan konseptual (Conseptual Approach). Jika metode pendekatan yang dipergunakan dalam penelitian adalah metode pendekatan normatif, yang secara deduktif, dimulai analisis terhadap pasal-pasal yang mengatur hal-hal yang menjadi permasalahan di atas, metode pendekatan ini digunakan dengan mengingat permasalahan yang diteliti berdasarkan pada peraturan-peraturan perundangundangan yaitu hubungan peraturan satu dengan peraturan lain serta kaitannya dengan penerapannya dalam praktek (Ediwarman, 2014).

Mengenai bahan/materi penelitian dalam penelitian berkaitan dengan data, oleh karena data yang diartikan sebagai informasi yang terkait dengan variabel yang dipertanyakan dalam permasalahan diperlukan untuk menjawab/ menyelesaikan permasalahan dalam penelitian yang bersangkutan. Data dalam suatu penelitian hukum lazimnya dibedakan antara sumber data yang 
diperoleh langsung dari responden, disebut dengan data primer dan data yang diperoleh dari bahan hukum disebut dengan data primer dan data yang diperoleh dari bahan hukum disebut dengan data sekunder (Elisabeth, 2018). Sumber dan jenis data dalam penelitian tesis ini dilakukan dengan melakukan pengumpulan data-data primer dan data sekunder yaitu:

Data primer merupakan data yang diperoleh secara langsung dari responden, oleh karenanya data primer merupakan data yang diperoleh oleh peneliti dan belum ada sebelumnya, atau dapat dikatakan bahwa penelitilah orang yang pertama menemukan data primer tersebut (Elisabeth, 2018). Data primer dalam penulisan tesis ini diperoleh dengan cara melakukan penelitian lapangan dengan melakukan wawancara pada Kantor Dinas Pemberdayaan Perempuan dan Perlindungan Anak Provinsi Sumatera Utara.

Data sekunder diperoleh melalui penelitian kepustakaan yaitu literatur-literatur dan peraturan perundang-undangan yang berhubungan dengan permasalahan yang akan diteliti. Data sekunder ini diperlukan untuk lebih melengkapi data primer yang diperoleh melalui penelitian dilapangan. Data-data sekunder meliputi Bahan hukum primer yaitu peraturan perundangundangan antara lain: Undang-Undang Dasar Negara Republik Indonesia Tahun 1945. UndangUndang Nomor 1 Tahun 1946 tentang KUHP. Undang-Undang Nomor 8 Tahun 1981 tentang KUHAP. Undang-Undang RI Nomor 4 Tahun 1979 tentang Kesejahteraan Anak. Undang-Undang Republik Indonesia Nomor 35 Tahun 2014 tentang Perubahan atas Undang-Undang Nomor 23 Tahun 2002 tentang Perlindungan Anak. Bahan hukum sekunder diperoleh dari buku, jurnal, makalah, artikel dan penelusuran dari internet yang berkaitan dengan permasalahan penyidikan tindak pidana pembunuhan biasa. Bahan hukum tersier yang dipergunakan yaitu kamus hukum, kamus bahasa dan ensiklopedia.

Prosedur pengambilan data dan pengumpulan data peneliti harus mengusahakan sebanyak mungkin data yang diperoleh atau dikumpulkan mengenai masalah-masalah yang berhubungan dengan peneliti, disini peneliti mempergunakan data primer dan sekunder data yang diperoleh dengan cara sebagai berikut: Studi kepustakaan, Studi kepustakaan ini untuk mencari konsepkonsep, teori-teori, pendapat-pendapat atau penemuan-penemuan yang berhubungan erat dengan pokok permasalahan. Kepustakaan tersebut dapat berupa: peraturan perundangundangan, karya ilmiah para sarjana dan lain-lain. Studi lapangan, Studi lapangan adalah cara memperoleh data yang bersifat primer. Dalam hal ini akan diusahakan untuk memperoleh datadata dengan mengadakan tanya jawab (wawancara) dengan berbagai aparat penegak hukum yang terlibat dalam proses peradilan pidana dan orang biasa yang tersangkut dalam proses peradilan pidana sebagai tersangka atau terdakwa (Ediwarman, 2014)

Analisis diartikan sebagai penyelidikan terhadap suatu peristiwa untuk mengetahui keadaan yang sebenarnya, sebab musabab, atau duduk perkaranya. Analisis data yaitu penelaahan dan penguraian atas data hingga menghasilkan kesimpulan. Analisis data berisi uraian tentang cara-cara analisis, yakni bagaimana memanfaatkan data yang terkumpul untuk dipergunakan dalam memecahkan masalah dalam peneliti yang dilakukan (Elisabeth, 2018).

Analisis data dalam penelitian hukum mempergunakan metode pendekatan kualitatif bukan kuantitatif, karena tanpa menggunakan rumusan statistik, sedangkan penggunaan angka-angka hanya sebatas angka persentase sehingga diperoleh gambaran yang jelas dan menyeluruh mengenai masalah yang diteliti. Prosedur pemecahan masalah tersebut menggunakan metode deskriptif karena masalah yang diselidiki dengan menggambarkan/melukiskan keadaan subyek/obyek penelitian (seseorang, lembaga, masyarakat dll). Pada saat sekarang berdasarkan fakta-fakta yang tampak sebagaimana adanya (Ediwarman, 2014).

Dalam suatu penelitian sebelumnya perlu di susun secara sistematis kemudian akan dianalisa dengan menggunakan prosedur logika ilmiah yang sifatnya kualitatif (Zainuddin, 2009). Setelah bahan hukum terkumpul kemudian dilakukan analisis untuk mendapatkan argumentasi akhir yang berupa jawaban terhadap permasalahan penelitian. Untuk itu setidak-tidaknya dapat digunakan empat macam teknik analisi yakni: deskripsi, komparasi, evaluasi dan argumentasi. Data yang telah dikumpulkan dengan studi kepustakaan dan wawancara tersebut selanjutnya dianalisis dengan mempergunakan metode analisis kualitatif yaitu penelitian tentang riset yang 
bersifat deskriptif (Diantha, 2019). Penyusunan data harus dipilih data yang ada hubungannya dengan penelitian, dan benar-benar otentik. Adapun data yang diambil melalui wawancara harus dipisahkan antara pendapat responden dan pendapat interviwer (Riduwan, 2014)

\section{HASIL DAN PEMBAHASAN}

\section{Faktor Penyebab Tindak Pidana Perdagangan Anak di Sumatera Utara}

Permasalahan perdagangan orang saat ini telah menjadi suatu keprihatinan bukan hanya bagi lingkup nasional, tetapi bagi dunia internasional juga. Hal ini mengingat sejumlah pelanggaran Hak Asasi Manusia (HAM) dianggap sebagai penyebab dan sekaligus akibat dari perdagangan orang. Pelanggaran HAM yang dimaksud seperti kerja paksa, eksploitasi seksual dan tenaga kerja, kekerasan, serta perlakuan sewenang-wenang terhadap para korbannya.

Para pelaku perdagangan orang secara licik telah mengeksploitasi kemiskinan, memanipulasi harapan dan kepolosan dari para korbannya dengan menggunakan ancaman, intimidasi dan kekerasan untuk membuat para korban menjalani perhambaan terpaksa, menjalani peonage, menjalani perhambaan karena hutang (debt bondage), dan perkawinan terpaksa atau palsu, terlibat dalam pelacuran terpaksa atau untuk bekerja dibawah kondisi yang sebanding dengan perbudakan untuk keuntungan bagi si pedagang (Talenta, 2021)

Korban tidak lagi diperlakukan seperti manusia, melainkan selayaknya budak yang dipaksa untuk memproduksi barang-barang murah ataupun memberikan layanan yang terus-menerus. Mereka hidup dalam ketakutan, dan banyak juga yang pada akhirnya menjadi korban kekerasan. Faktor-faktor yang paling mendukung adanya perdagangan orang diantaranya karena adanya permintaan (demand) terhadap pekerjaan di sektor informal yang tidak memerlukan keahlian khusus, mau dibayar dengan upah relatif rendah serta tidak memerlukan perjanjian kerja yang rumit, sehingga menyebabkan pelaku (trafficker) terdorong untuk melakukan bisnis trafficking.

Dari segi ekonomi kegiatan usaha bisnis seperti ini dapat mendatangkan keuntungan yang sangat besar serta adanya celah hukum yang menguntungkan para trafficker yaitu kurangnya penegakan hukum di Indonesia, terutama dalam mengadili pelaku perdagangan orang, termasuk pemilik/pengelola/perusahaan pengerah tenaga kerja, sehingga mereka dapat memanfaatkan korban dan calon korban perdagangan orang (Talenta, 2021).

Modus operandi rekrutmen terhadap kelompok rentan biasanya dengan rayuan, menjanjikan berbagi kesenangan dan kemewahan, menipu atau janji palsu, menjebak, mengancam, menyalahgunakan wewenang, menjerat dalam hutang, mengawini atau memacari, menculik, menyekap atau memerkosa. Modus lain berkedok mencari tenaga kerja untuk bisnis entertainment, kerja di perkebunan atau bidang jasa di luar negeri dengan upah besar. Ibu-ibu hamil yang kesulitan biaya untuk melahirkan atau membesarkan anak dibujuk dengan jeratan hutang supaya anaknya boleh diadopsi agar dapat hidup lebih baik, namun kemudian dijual kepada yang menginginkan. Anak-anak di bawah umur dibujuk agar bersedia melayani para pedofil dengan memberikan barang-barang keperluan mereka bahkan janji untuk disekolahkan.

Daerah yang selama ini menjadi sumber rekruitmen di Kota Medan adalah Medan Tembung, Medan Labuhan, Medan Helvetia, Medan Baru, dan Medan Amplas. Dari hasil penelitian di Lembaga Swadaya Masyarakat Pusaka Indonesia diperoleh data berdasarkan daerah asal sebagai berikut. Daerah transit dalam perdagangan manusia merupakan daerah-daerah penampungan yang menjadi tempat para korban singgah sementara sebelum mencapai daerah tujuan. Rata-rata daerah ini merupakan kota-kota yang memiliki akses transportasi yang memadai untuk memberangkatkan para korban.

Daerah Medan yang biasa dijadikan daerah transit perdagangan manusia adalah: Pelabuhan laut Belawan, Bandara Polonia, Padang Bulan Penginapan. Tujuan perdagangan manusia di Indonesia adalah daerah-daerah di dalam dan luar negeri. Meski secara umum daerah primadona tujuan perdagangan untuk dalam negeri meliputi kota-kota besar dan kota-kota atau pulau tujuan wisata.

Menurut Sitiani Purba, di Medan korban dibawa ke pub, panti pijat, cafe, hotel, karaoke, barak-barak penampungan atau lokalisasi pelacuran, salon dan sebagai pekerja rumah tangga. Di Provinsi Sumatera Utara, umumnya korban dibawa ke daerah Bandar Baru, Bukit Maraja, Warung Bebek, dan hotel-hotel melati di Kota Medan (Maidi, 2018). 
Kemiskinan. Rendahkannya pendapatan yang diterima dalam suatu keluarga merupakan suatu alasan umum yang sering digunakan oleh pelaku untuk mengesahkan terjadinya kejahatan termasuk juga kejahatan child trafficking. Keluarga yang seharusnya menjadi pelindung anakanaknya malah merupakan pelaku kejahatan child trafficking.

Hal ini terjadi ketika orangtua atau wali yang seharusnya merupakan pelindungan si anak malah tega untuk menjual anaknya kepada makelar untuk dijadikan sebagai pelacur. Dibeberapa daerah tertentu di Indonesia ada suatu pandangan bahwa anak perempuan adalah salah satu aset yang mendatangkan keuntungan besar, sehingga orang tua kandung sampai hati menjual anak perempuannya kerena harga yang sangat tinggi, khususnya harga keperawanan. Selalin itu faktor yang menyebabkan orang tua tega menjal anaknya sendiri adalah karena jerat hutang, orang tua kadang meminjam uang kepada seorang rentenir yang ternyata ia juga berprofesi sebagai germo. Ketika jatuh tempo dan ternyata uang yang dipinjam belum lunas terbayar maka anak perempuan pengutang diminta bekerja pada rentenir tersebut, namun ternyata pekerjaan yang disuruh lakukan adalah sebagai pelacur. Tindakan tersebut tidak hanya sebatas itu saja kadang apabila pekerjaannya ditempat yang jauh maka biaya perjalanan dihitung pula sebagai hutang. Kemiskinan yang mendera dalam suatu keluarga mengakibatkan tidak tercukupinya kebituhan hidup keluarga sehingga ada suatu tekanan yang secara psikis mendera anak tersebut kemudian menjadi suatu pola pikir dari setiap anggota keluarga bahwa mereka harus bekerja untuk mencukupi kebutuhannya sendiri sekaligus membantu perekonomian keluarga.

Rendahnya Tingkat Pendidikan. Salah satu efek dari kemiskinan adalah tidak adanya peluang untuk memperoleh pendidikan yang layak, mereka rata-rata hanya berasal dari lulusan setingkat SD/SMP atau yang lebih parah mereka ada yang tidak lulus karena drop out dari sekolahnya karena tidak dapat membayar biaya sekolah. Rendahnya pendidikan dan kurangnya informasi tentang trafficking berdampak pada mudahnya anak-anak menjadi korban child trafficking. Mereka begitu mudah untuk menerima bujuk rayu yang dilakukan oleh trafficker untuk diajak bekerja dengan iming-iming akan dipekerjakan sebagai pelayan restoran, baby sister, atau menjadi TKI.

Masa dimana pekerjaan sangat sulit untuk didapatkan menjadikan anak mau menerima tawaran pelaku tanpa ada suatu prasangka yang buruk, hal ini disebabkan adanya suatu pemikiran yang logis bahwa setelah mereka mendapatkan pekerjaan semua biaya yang telah dikeluarkan oleh trafficker untuk mengangkutnya dapat dikembalikan. Mereka dapat mengganti uang pinjaman trafficker jika sudah mendapatkan gaji dari pekerjaan yang akan nantinya akan mereka kerjakan.

Bujukan tersebut dengan mudah diterima tanpa berfikir panjang apakah pekerjaan yang nantinya akan mereka kerjakan benar-benar sesuai dengan yang dijanjikan, atau mereka benarbenar akan dipekerjakan di daerah yang seperti dikatakan oleh trafficker. Kurangnya informasi mengenai kejahatan child trafficking juga menyebabkan mereka mudah dibujuk untuk ikut bekerja di luar negeri atau pergi di daerah lain.

Korban Perceraian Orang Tua. Anak-anak yang korban perceraian orang tua (broken home) adalah mereka yang tinggal dengan salah satu orang tuanya akibat perceraian atau mereka yang tinggal di dalam keluarga yang tidak memiliki keharmonisan sehingga selalu saja bertengkar.Keadaan yang demikian membuat anak tidak mendapatkan perhatian dari kedua orang tuanya.

Anak-anak yang berlatar belakang dari keluarga broken home mengaku bahwa akibat dari pertengkaran orangtuanya menyebabkan mereka menjadi korban, karena sang ayah sering melakukan tindak kekerasan berupa pemukulan atau penamparan pada mereka ketika mereka melakukan sedikit kesalahan. Ada pula yang setelah orangtuanya bercerai dan menikah kembali dengan orang lain tidak dapat mengubah keadaan menjadi lebih karena mereka mengalami kekerasan berupa pemukulan selalu dimarahi oleh orangtua tirinya, ada pula yang setelah orang tua mereka bercerai menyebabkan anak diterlantarkan oleh kedua orangtuanya.

Hal inilah yang menyebabkan mereka memilih kabur dari rumah atau memilih melampiaskan kesendiriannya dengan pergi bersama teman-temannya ketempat yang dapat 
memberikan hiburan.Keberadaan anak-anak tersebut tempat hiburan malam atau kafe dengan kapasitas yang terlalu sering bisa menyebabkan mereka terkontaminasi dengan keadaan yang ada seperti kebiasaan mengkonsumsi narkoba atau melakukan seks bebas dengan temannya sendiri.Terlibanya anak tersebut dengan narkoba menyebabkan mereka menjadi pecandu, dengan keadaan seperti itu mereka harus memiliki uang agar tetap dapat mengkonsumsi narkoba. Tanpa adanya uang untuk membeli narkoba memaksa mereka bekerja karena ketidakpedulian orangtua tidak memberikan uang kembali, dan salah satu pilihan pekerjaan yang dapat memberikan uang banyak dan cepat adalah dengan sebagai Pekerja Seks Komersial (PSK). Pekerjaan tersebut dipilih karena teman-temannya juga melakukan pekerjaan yang serupa diskotek atau kafe, dari merka si anak tahu bahwa pekerjaan tersebut dapat menjadikan pendapatan yang besar dan cepat selain itu karena alasan bahwa ia juga sudah pernah melakukan hubungan seks dengan pacarnya jadi mereka tidak keberatan melakukan hal tersebut .

Pengalaman Seksual Dini. Pengalaman seks dini yang dimaksud adalah anak sudah pernah melakukan hubungan seksual dengan lawan jenisnya sebelum usianya dewasa. Banyak hal yang menyebabkan anak melakukan hubungan seksual diusia yang masih kecil antara lain disebabkan karena: Pergaulan Bebas; Anak melakukan hubungan seksual dengan pacar atau temannya karena teman-temannya juga melakukan hal yang serupa.

Faktor lingkungan pergaulan tersebut secara langsung atau tidak langsung dapat mempengaruhi anak untuk mengikuti kebiasaan yang dilakukan oleh kelompok tersebut agar ia dapat diterima oleh lingkungannya. Teman-teman yang ia pilih dapat menyebabkan mereka menjadi baik atau buruk ketika ia memilih begaul dengan teman-teman yang memiliki pola pergaulan yang bebas maka anak tersebut akan terkondisikan dengan hal itu sehingga ia menganggap bahwa melakukan hubungan seksual dengan lebih dari satu orang bukanlah merupakan hal yang tabu lagi.

Pernah Mengalami Kekerasan Seksual/Pemerkosaan. Pemerkosaan adalah salah satu sebab yang mengakibatkan anak terjerumus dalam prostitusi.Umumnya secara sadar mereka menjerumuskan diri dalam prostitusi karena meresa sudah tidak suci lagi dan malu karena pernah diperkosa. Pelaku pemerkosaan bisa dilakukan oleh orang yang dekat dengannya seperti ayah, kakak, saudara, teman, pacar, atau bisa juga dilakukan oleh orang yang tidak dikenal. Adanya suatu pandangan seksualitas yang menekankan arti keperawanan sehingga tidak memberi kesempatan bagi mereka yang sudah tidak perawan untuk menentukan dirinya, sehingga berdasarkan pada anggapan tersebut mereka sadar untuk menunjukkan duru dalam dunia prostitusi.

Pencari Kerja. Krisis moneter yang terjadi di Indonesia mengakibatkan banyak sekali tenaga kerja yang di PHK karena banyak perusahaan yang mengalami kebangkrutan. Banyaknya tenaga kerja yang di PHK ditambah dengan banyaknya orang yang berusia kerja menyebabkan banyak sekali pengangguran yang disebabkan belum tersedianya lapangan pekerjaan yang disediakan oleh negara. Kurangnya lapangan pekerjaan membuat mereka memilih alternatif untuk bekerja di luar negeri. Kesempatan seperti itu yang digunakan oleh calo untuk merekrut atau menarik para perempuan untuk bekerja di luar negeri atau di daerah lain sebagai baby sister, pembantu rumah tangga, dengan iming-iming gaji yang besar untuk setiap bulannya. Penyalur jasa tenaga kerja yang illegal memanfaatkan hal tersebut, ia membujuk para pencari kerja terutama anak-anak untuk diajak bekerja dengannya tanpa harus memikirkan biaya transportasi dan akomodasi karena semua biaya itu ditanggung oleh calo dan dapat dibayar setelah mereka mendapatkan gaji.

Mereka tidak tahu pasti kemana mereka akan ditempatkan kalaupun diberi tahu hanya provinsi atau kota mereka akn bekerja tetapi tidak tahu persis dimana tempatnya. Sesampainya mereka di tempat tersebut bayangan akan rumah atau tempat penampungan untuk pelatihan sirna karena saat mereka tiba mereka disekap atau ditempatkan diruang yang terisolasi sebelum mereka dipindahkan ke daerah tujuan. Selama di dalam penampungan mereka tidak diberi makan dan juga mengalami kekerasan secara fisik.

Beberapa hari berada di tempat transit mereka diberangkatkan ke daerah tujuan dan disanalah mereka akan dipekerjakan sebagai pelacur. Tempat tujuan yang ditunjuk seperti diskotek, panti pijat, kafe, dll, pertama kali mereka mengetahui bahwa mereka harus 'melayani tamu' mereka menolak untuk melakukan hal tersebut namun hal itu menyebabkan mucikari 
melakukan penyiksaan, tidak hanya kekerasan verbal mucikari juga tidak akan memberikan makan sampai mereka mau bekerja padanya.

Melakukan pekerjaan seperti yang disuruh bukan berarti bahwa mereka terlepas dari masalah, mereka tidak diberi gaji selama beberapa bulan dengan alasan bahwa gaji merek digunakan untuk membayar seluruh biaya yang sudah dibayarkan untuk mucikari kepada calo yang membawa mereka dari desa, sehingga mereka hanya mendapatkan makan dan juga tempat tinggal. Gaji mereka pun tak kunjung dibayarkan walaupun hutang mereka sudah lunas kalaupun diberi uang hanyalah beberapa ribu saja karena uang tersebut dipotong untuk membiayai selama mereka bekerja disana (Talenta, 2021).

Secara hukum telah dibentuk UU No 21 tahun 2007 tentang tindak pidana perdagangan orang, peraturan presiden nomor 69 tahun 2008 tentang pembentukan gugus tugas, namun permasalahan yang paling terlihat adalah kurang adanya sosialisasi mengenai TPPO kepada baik pemangku kepentingan tingkat pusat dan daerah maupun kepada masyarakat luas sehingga pelaksanaan dilapangannya kurang maksimal. Selain itu, kendala juga terlihat pada mekanisme pelaporan dan evaluasi yang belum berjalan dengan baik di lapangan. Terkait koordinasi permasalahan yang sering terjadi adalah perwakilan kementerian lembaga yang sering bergantiganti sehingga komunikasi kadangkala tidak berkesinambungan.

Kendala yang dihadapi yaitu, pelayanan di tingkat daerah : Keterbatasan SDM; Sistem Pendataan yang kurang baik; Pendataan Akta kelahiran yang belum menyeluruh diakibatkan maraknya perkawinan yang tidak sah dan kasus hamil di luar nikah; Sosialisasi terhadap masyarakat yang kurang menyeluruh; Sindikat perdagangan orang yang belum dapat di berantas secara menyeluruh; Kurangnya kerjasama antara penegak hukum tentang pentingnya pencegahan dan pemberantasan tindak pidana perdagangan orang.

\section{Kebijakan Dalam Mencegah Dan Mengatasi Pelaku Perdagangan Orang}

Dalam era kemerdekaan yang demokratis dengan masyarakat yang religius dan menjunjung tinggi Hak Asasi Manusia, Bangsa Indonesia terus meningkatkan komitmennya untuk mensejahterakan kehidupan Bangsa melalui upaya-upaya yang diselenggarakan secara konsisten dan berkelanjutan dalam melindungi warga negaranya antara lain dari praktek-praktek perdagangan orang dan bentuk-bentuk eksploitasi lainnya (Wikisource, 2021).

Penguatan komitmen Bangsa Indonesia yang diwujudkan dalam bentuk Keputusan Presiden No. 88 Tahun 2002 tentang Rencana Aksi Nasional Penghapusan Perdagangan Perempuan dan Anak (RAN-P3A) serta pembentukan Gugus Tugas lintas sektoral untuk implementasinya, telah menggiatkan upaya memerangi perbudakan modern perdagangan orang secara lebih terencana, terintegrasi dengan langkah-langkah untuk mengatasi akar masalahnya: kemiskinan, kurangnya pendidikan dan keterampilan, kurangnya akses, kesempatan dan informasi serta nilai-nilai sosial budaya yang memarginalkan dan mensubordinasikan kaum perempuan.

Kerjasama antar unsur internal dalam negeri dan dengan negara sahabat serta lembaga internasional semakin meluas dan menguat, dan akan terus dibina sehingga terwujud sumber daya yang lebih kuat untuk memerangi perdagangan orang yang telah menjadi kejahatan transnasional yang terorganisir. Perhatian khususnya ditujukan untuk melindungi korban, tetapi dalam waktu yang bersamaan, melalui pembinaan aparat dan komunitas masyarakat, diupayakan penindakan hukum yang lebih keras kepada trafficker agar menimbulkan efek jera. Berbagai upaya penyuluhan, kampanye, dan peningkatan kepedulian masyarakat juga terus dilakukan untuk mencegah terjeratnya kelompok rentan dalam perdagangan orang.

Penguatan komitmen Pemerintah RI dalam penghapusan perdagangan orang tercermin dari Keputusan Presiden RI No. 88 Tahun 2002 tentang: Rencana Aksi Nasional Penghapusan Perdagangan Perempuan dan Anak (RAN P3A) dan pengajuan Rencana Undang-undang Penghapusan Tindak Pidana Perdagangan Orang (RUU PTPPO) kepada DPR RI untuk disahkan. Dalam Program Legislasi Nasional 2005-2009, RUU Tindak Pidana Perdagangan Orang berada di urutan 22 dari 55 prioritas RUU yang akan dibahas Tahun 2005 (Wikisource, 2021). 
Peningkatan perlindungan kepada korban perdagangan orang dilaksanakan dengan meningkatkan aksesibilitas layanan melalui pembentukan Pusat Pelayanan Terpadu di Rumah Sakit Umum milik Pemerintah Pusat, Propinsi dan Kabupaten/Kota serta Rumah Sakit Kepolisian Pusat dan Rumah Sakit Bhayangkara di daerah. Ruang Pelayanan Khusus Kepolisian yang dikelola oleh Polisi Wanita semakin ditambah yang kini jumlahnya mencapai 226 unit di 26 Kepolisian Daerah (Propinsi) dan masih akan terus diperluas ke Kepolisian Daerah yang lain dan Kepolisian Resort (Kabupaten/Kota) seluruh Indonesia. Di samping itu juga semakin banyak LSM dan organisasi masyarakat yang mendirikan women's crisis centre, Drop In Center, atau shelter yang kini jumlahnya 23 unit yang tersebar di 15 propinsi. Di samping itu, untuk pengungsi di Aceh telah didirikan sedikitnya 20 unit Children Center "Jambo Anak Metuah" bekerjasama dengan UNICEF dan Departemen Sosial. Lembaga bantuan hukum dan LSM yang sebagian tugasnya juga memberikan bantuan hukum kepada korban perdagangan orang kini semakin banyak tersebar di berbagai kabupaten/kota.

Pemerintah bekerjasama dengan semua pihak: LSM lokal, nasional dan internasional serta dengan badan-badan dunia mengupayakan program pemberdayaan para mantan korban perdagangan orang pasca reintegrasi untuk mencegah mereka terjebak kembali dalam perdagangan orang demikian pula untuk keompok masyarakat yang rentan. Program pemberdayaan ini terintegrasi dengan upaya pengentasan kemiskinan dan peningkatan pendidikan yang ditengarai merupakan akar masalah dari perdagangan orang (Wikisource, 2021).

Peranan Pemerintah Propinsi Sumatera Utara membantu penyidik Polri dalam upaya penghapusan perdagangan (trafficking) salah satunya dengan mengeluarkan Perda No. 6 Tahun 2004, tentang Penghapusan Perdagangan (Trafiking) Perempuan dan Anak dan Peraturan Gubernur Sumatera Utara No. 24 Tahun 2005 tentang Rencana Aksi Provinsi Penghapusan Perdagangan (Trafficking) Perempuan dan Anak dan dalam Peraturan Gubsu tersebut terbentuk Gugus Tugas Rencana Aksi Provinsi Penghapusan Perdagangan (Trafficking) Perempuan dan Anak (RAP-P3A), sebagaimana yang diamanatkan Keputusan Presiden No. 88 Tahun 2002 tentang: Rencana Aksi Nasional Penghapusan Perdagangan (trafficking) perempuan dan anak (RAN-P3A). RAN-P3A tersebut merupakan landasan pedoman bagi Pemerintah dan Masyarakat dalam melaksanakan Penghapusan Perdagangan (trafficking) Perempuan dan Anak. Hakekat dan tujuan RAN-P3A (Wikisource, 2021) adalah untuk : Menjamin peningkatan dan pemajuan atas upaya perlindungan terhadap korban perdagangan (trafficking) perempuan dan anak; Mewujudkan kegiatan-kegiatan baik yang bersifat preventif maupun represif dalam upaya melakukan pencegahan dan penanggulangan atas praktek-praktek perdagangan (trafficking) perempuan dan anak.

Mendorong untuk adanya pembentukan dan /atau penyempurnaan peraturan yang berkaitan dengan tindakan perdagangan (trafficking) perempuan dan anak. Untuk menjamin terlaksananya RAN-P3A dibentuk satu gugus tugas nasional sementara untuk menjamin terlaksananya RAN-P3A didaerah dilakukan oleh gugus tugas daerah.

Pemerintah Propinsi Sumatera Utara telah mengeluarkan Peraturan Gubernur Sumatera Utara No. 24 Tahun 2005 tentang Rencana Aksi Propinsi Penghapusan Perdagangan (trafficking) perempuan dan anak (RAP-P3A). Hal terpenting dalam Peraturan Gubsu tersebut adalah Stakeholders (pihak-pihak terkait) di Provinsi Sumatera Utara. Dalam upaya penghapusan perdagangan (trafficking) perempuan dan anak, pihak terkait berperan dan bertanggung jawab sesuai dengan tugas pokok dan fungsi serta kewenangannya masing-masing.

Aksi Provinsi Penghapusan Perdagangan (Trafficking) Perempuan dan Anak (RAP-P3A) di Sumatera Utara, sangat penting dalam upaya memerangi perbudakan modern trafficking secara terencana, terintegrasi dengan langkah-langkah untuk mengatasi akar permasalahan yakni: kemiskinan, kurangnya pendidikan dan ketrampilan, kurangnya akses kesempatan dan informasi serta nilai-nilai sosial budaya yang memarginalkan dan mensubordinasikan kaum perempuan, dimana sebagai penggiat (Focal Point) dari pihak Pemerintah Provinsi Sumatera Utara adalah Biro Pemberdayaan Perempuan dan Anak serta Keluarga Berencana Sekretariat Daerah Provinsi Sumatera Utara (Wikisource, 2021). 


\section{Kebijakan Yang Dilakukan Dalam Mencegah Dan Mengatasi Pelaku Perdagangan Orang Terhadap Anak Dibawah Umur}

Bahwa bertitik tolak pada sebab-sebab timbulnya kejahatan tersebut di atas dapat dicari jalan keluarnya dalam rangka upaya penanggulangannya antara lain: Tahap pertama apa yang disebut pre-entif, tahap kedua yaitu preventif, tahap ketiga yaitu represif (Ediwarman, 2014). Upaya-upaya pencegahan kejahatan memiliki dampak yang amat berbeda-beda pada tingkat kejahatan dan ketakutan dalam masyarakat. Tak ada pendekatan tunggal bagi pencegahan kejahatan yang telah terbukti dapat diterapkan bagi segala situasi. Memang kebanyakan intervensi tampak berhasil dalam latar-latar terbatas dengan tipe-tipe pelanggar hukum dan masalah kejahatan yang terbatas pula. Ada kebutuhan yang jelas untuk mengidentifikasi teknik pencegahan kejahatan yang tepat dengan situasi yang tepat. Lepas dari ketiadaan dukungan yang konsisten dalam segala evaluasi atas berbagai teknik pencegahan kejahatan, beberapa intervensi yang menjanjikan telah muncul dalam masing-masing dari tiga wilayah pencegahan kejahatan umum (Lab, 2012).

Pencegahan Primer. Teknik-teknik pencegahan primer terus memiliki daya tarik intuitif besar sehubungan dengan keterlibatan publik umum dalam pencegahan kejahatan. Kegagalan sistem keadilan kriminal untuk mengurangi kejahatan dan ketakutan akan kejahatan mengilustrasikan bahwa sistem formal kurang lengkap sarananya untuk menangani masalahmasalah ini. berbagai pencegahan kejahatan di tingkat rukun tetangga dapat melibatkan jauh lebih banyak orang, dari pada petugas hukum. Para warga lokal menyediakan kehadiran yang konstan di sebuah wilayah.

Peran utama dari para aparat keadilan formal dalam pencegahan primer adalah mendukung dan berpartisipasi dalam beragam bentuk intervensi. Polisi adalah sumber primer informasi mengenai kejahatan dan dalam posisi mengidentifikasi masalah, mengontak para warga serta melaporkan berbagai program untuk memerangi kejahatan.

Sistem hukum formal dapat berpartisipasi secara langsung dalam pencegahan primer melalui fungsi penangkalan kejahatan umum dalam sistem pemberian sangsi. Penangkalan umum tersebut mengasumsikan bahwa hukuman atau sangsi bagi beberapa individu dapat berfungsi sebagai contoh bagi individu lain yang sedang berpikir-pikir hendak melakukan kegiatan menyimpang.

Pencegahan Sekunder. Pencegahan sekunder memindahkan pencegahan kejahatan lebih jauh ke tangan sistem hukum yang ada. Publik tak lagi di pandang sebagai aktor utama dalam menangani kejahatan. Salah satu alasan utama untuk pengalihan ini adalah tekanan dalam bekerja dengan para individu dan situasi yang menampakkan sebuah potensi perlawanan hukum yang jelas. Manipulasi kemasyarakatan umum, seperti yang bisa kita temukan dalam pencegahan primer, diperhalus serta diarahkan pada pribadi-pribadi spesifik. Namun, intervensi sebelum sebuah aksi melawan hukum dilakukan barulah merupakan tujuan. Pencegahan sekunder berbeda upaya untuk mengidentifikasi atau meramalkan siapa yang harus disasar dalam sebuah intervensi. Namun, ramalam dalam kriminologi, tetaplah merupakan sebuah sasaran yang elusif. Ramalanramalan klinis dan aktuarial sering menghasilkan kesalahan ketimbang menyediakan klasifikasi yang benar. Karena itu banyak program yang salah sasaran, menangani orang-orang yang tak perlu atau tak selayaknya jadi sasaran intervensi. Sementara individu-individu lain yang harus ditangani malah entah kenapa dibiarkan saja terus membahayakan masyarakat (Lab, 2012).

Pencegahan Tersier. Wilayah pencegahan tersier tetaplah secara kuat berada dalam wilayah sistem hukum formal. Masalah-masalah menumbuhkan partisipasi, dukungan publik, atau peramalan perilaku kemudian, bukanlah sesuatu yang terkait dengan pendekatan tersier. Tekanan diberikan pada pengurangan residivisme. Penangkalan spesifik, pelumpuhan, serta rehabilitasi, menjadi sokoguru bagi pencegahan tersier. Sayangnya, tak satupun dari intervensi ini menjanjikan pengurangan aksi penyimpangan di masa depan. Penangkalan spesifik bertujuan untuk mencegah pelanggaran kejahatan dari transgresi di masa depan dengan memaksakan hukuman bagi perilaku kriminal mereka. Hanya sedikit penelitian yang meneliti dampak penangkalan spesifik sebuah hukuman. Sedangkan penelitian yang ada gagal menunjukkan efek yang cukup berarti (Lab, 2012). 
Upaya Pemberantasan Tindak Pidana Perdagangan Orang dapat dilakukan secara preemtif, preventif dan represif. Upaya Pre-emtif. Yang dimaksud dengan upaya pre-emtif adalah upayaupaya awal yang dilakukan oleh pihak kepolisan untuk mencegah terjadinya tindak pidana. Usahausaha yang dilakukan dalam penanggulangan kejahatan secara pre-emtif adalah menanamkan nilai-nilai norma-norma yang baik sehingga norma-norma tersebut terinternalisasi dalam diri seseorang. Meskipun ada kesepakatan untuk melakukan pelanggaran/kejahatan tapi tidak ada niatnya untuk melakukan hal tersebut maka tidak akan terjadi kejahatan. Jadi, dalam usaha preemtif faktor niat menjadi hilang meskipun ada kesempatan.

Dalam mencegah tindak pidana perdagangan orang langkah awal yang dapat dilakukan adalah dengan sosialisasi mengenai kejahatan perdagangan orang yang merupakan perbuatan yang melanggar hak asasi manusia terkhususnya hak perempuan dan anak karena dapat merugikan diri sendiri maupun orang lain serta menanamkan nilai kemanusiaan kepada setiap masyarakat agar dapat melindungi diri sendiri atau orang terdekatnya untuk menjauhi perbuatan/kejahatan yang akan memberikan dampak buruk bagi dirinya (Talenta, 2021).

Upaya Preventif. Upaya-upaya preventif ini adalah merupakan tindak lanjut dari upaya PreEmtif yang masih dalam tataran pencegahan sebelum terjadinya kejahatan. Dalam upaya preventif yang ditekankan adalah menghilangkan kesempatan untuk melakukan kejahatan. Salah satu bentuk kejahatan yang dilakukan melintasi batas dan dalam wilayah negara, adalah kejahatan perdagangan oraang. Tindak pidana perdagangan orang sudah menjadi agenda dalam penegakan hukum dan menjadi pusat perhatian dunia internasional, karena dampaknya dapat mengganggu kesejahteraan sosial. Mengingat ruang lingkup dan dimensinya sudah meluas, maka kegiatan TPPO dapat dimasukkan sebagai organized crime, white collar crime, corporate crime, cyber crime dan bahkan transnational crime.

Berbagai upaya untuk melakukan pencegahan kejahatan perdagangan orang sudah dilakukan dengan berbagai cara namun hasilnya dianggap belum memuaskan, bahkan upaya dengan menggunakan sarana hukum juga masih belum menunjukkan hasil yang signifikan. Penggunaan upaya hukum sebagai ultimum remedium, dimaksudkan sebagai salah satu upaya untuk mengatasi masalah sosial, termasuk bidang kebijakan penegakan hukum, sebagai upaya yang rasional untuk mencapai kesejahteraan masyarakat. Upaya pencegahan merupakan suatu pencegahan kejahatan, dimana dilakukan sebelum kejahatan itu terjadi, upaya ini seharusnya lebih diutamakan daripada upaya yang bersifat represif.

Dalam melaksanakan pencegahan (preventif) perlu dilakukan kerjasama dari pemerintah, satuan gugus tugas, masyarakat dan kerjasama Internasional, yang diharapkan dapat mengurangi atau mengurungkan terjadinya tindak perdagangan orang.

Upaya Represif. Upaya ini dilakukan pada saat telah terjadi tindak pidana/kejahatan yang tindakannya berupa penegakan hukum (law enforcement) dengan menjatuhkan hukuman. Penggunaan hukum pidana merupakan bagian dari kebijakan/politik hukum yang secara keseluruhan merupakan politik kriminal atau social defence planning, yang merupakan bagian integral dari rencana pembangunan nasional.

Dalam penanggulangan secara represif cara-cara yang ditempuh bukan lagi pada tahap bagaimana mencegah terjadinya suatu kejahatan tetapi bagaimana menanggulangi atau mencari solusi atas kejahatan yang sudah terjadi. Atas dasar itu kemudian, langkah-langkah yang biasa ditempuh cenderung bagaimana menindak tegas pelaku kejahatan atau bagaimana memberikan efek jera terhadap pelaku kejahatan. Tindak pidana perdagangan orang adalah salah satu jenis dari tindakan/perbuatan yang dinamakan kejahatan, dan kejahatan dalam istilah yuridis disebut tindak pidana. Menurut Saparinah Sadli kejahatan merupakan salah satu bentuk dari perilaku menyimpang yang selalu ada dalam masyarakat, dan dalam realita tidak ada masyarakat yang sepi dari kejahatan. Perilaku menyimpang ini, merupakan ancaman terhaadap norma-norma sosial yang mendasari kehidupan/keteraturan sosial; dapat menimbulkan ketegangan sosial; dan merupakan ancaman riil atau potensial bagi ketertiban.

Berbagai upaya telah dan sedang dijalankan pemerintah Indonesia untuk memerangi kejahatan perdagangan orang, melalui upaya-upaya pencegahan dan pemberantasan perdagangan orang, yaitu dengan menghasilkan suatu peraturan hukum yang khusus menanggani tindak pidana perdagangan orang. Tahap kebijakan formulasi/legislasi adalah tahap yang paling strategis, 
karena pada tahap ini akan dihasilkan suatu peraturan hukum yang akan menjadi pedoman pada tahap-tahap berikutnya dalam pross kebijakan hukum. kebijakan formulasi dapat berupa kriminalisasi/pembaruan hukum dengan menciptakan aturan baru, atau dapat berupa regulasi yang merubah dan menambah/merevisi peraturan lama. Secara umum, pembaruan hukum pidana dapat dilakukan untuk seluruh bagian hukum pidana secara global/menyeluruh, ataupun secara parsial/bagian baik hukum pidana umum maupun hukum pidana khusus. Salah satu bagian hukum pidana khusus yang merupakan hasil formulasi di bidang hukum pidana adalah tindak pidana perdagangan orang.

Upaya penanggulangan kejahatan secara penal lebih menitik beratkan pada sifat repressive (penindasan/pemberantasan/penumpasan), sesudah kejahatan terjadi. Tindakan secara penal yang dilakukan untuk memberantas perdagangan orang dapat dilakukan dengan menerapkan Undang-Undang Nomor 21 Tahun 2007(UU PTPPO) bagi pelaku yang telah memenuhi setiap unsur/komponen utama tindak pidana perdagangan orang. Tindakan secara penal yakni penerapan hukum pidana guna menjerat pelaku dalam memaksimalkan hukum untuk memberikan efek jera, melalui proses pemeriksaan ditingkat Polisi, Jaksa dan Hakim di Pengadilan.

Penanggulangan represif menurut pendapat Bambang Purnomo, yaitu tindakan dari petugas hukum terhadap perbuatan seseorang yang dilakukan setelah terjadinya pelanggaran hukum. Penanggulangan tindak pidana ini dimulai dari tindakan pengusutan dan penyediaan barang bukti oleh polisi, tindakan penuntutan oleh jaksa, kemudian dilanjutkan dengan pemeriksaan dalam sidang pengadilan oleh hakim mengutamakan analisa dari kejadian yang berakibat melanggar dan aturan hukum yang bersangkutan untuk memperoleh putusan hakim dan berakhir dengan pelaksanaan putusan.

Undang-Undang Nomor 21 Tahun 2007 tentang Pemberantasan Tindak Pidana Perdagangan Orang, merupakan upaya memberikan perlindungan hukum baik langsung atau tidak langsung kepada korban dan/atau calon korban agar tidak menjadi korban di kemudian hari. Selain itu pemerintah Indonesia dewasa ini sudah meratifikasi United Againts Transnational Organized Crime (Konvensi Perserikatan Bangsa-Bangsa Menentang Tindak Pidana Transnasional yang Terorganisasi) menjadi Undang-Undang Nomor 5 Tahun 2009. Dengan diratifikasinya Konvensi PBB tersebut, berarti Indonesia sudah berupaya untuk melakukan pencegahan dan penanggulangan tindak pidana perdagangan orang.

Lahirnya Undang-Undang PTPPO disambut gembira oleh masyarakat Indonesia dan komunitas internasional yang peduli masalah perdagangan orang. Terbitnya Undang-Undang ini merupakan suatu prestasi karena dianggap sangat komprehensif dan mencerminkan ketentuan yang diatur dalam Protokol PBB. Indonesia sebagai negara yang menandatangani Protokol PBB, mempunyai kesepakatan dengan komunitas internasional tentang bagaimana melihat perdagangan orang sebagai kasus yang multi kompleks yang harus ditangani secara komprehensif, melalui lima langkah penting penangganan yaitu; Penindakan, Pencegahan, Rehabilitasi Sosial, Perlindungan bagi Korban, Kerjasama dan Peran Serta masyarakat. Undang-Undang PTPPO yang terdiri dari 9 bab yang meliputi 67 pasal, yang melihat perdagangan orang sebagai kasus yang multikompleks harus ditangani secara komprehensif melalui lima langkah tersebut (Talenta, 2021).

Upaya-upaya diatas merupakan pencegahan kejahatan atau tindak pidana menggunakan upaya non penal dan penal. Upaya non penal yang banyak digunakan dalam kebijakan-kebijakan Internasional melalui berbagai konvensi dan pemerintah daerah melalui peraturan daerahnya. Upaya non penal yang diatur dalam kebijakan-kebijakan diatas berupa tindakan-tindakan untu mencegah tindak pidana perdagangan orang yang menekankan pada bidang administrasi dan pembukaan lapangan pekerjaan.

Kebijakan Penanggulangan Perdagangan Perempuan Dan Anak. Upaya perlindungan terhadap korban kejahatan perdagangan manusia salah satunya adalah melalui pencegahan dan pemberantasan kejahatan perdagangan manusia. Barda Nawawi Arief menyatakan bahwa 
perlidungan korban dapat juga dilihat sebagai perlindungan hukum untuk tidak menjadi korban kejahatan (Arief, 2001).

Pemerintah kota medan juga ikut serta membantu proses reintegrasi dan rehabilitasi sesuai dengan pasal 8 ayat 28 Perda Kota Medan Nomor 3 Tahun 2017 tentang Pencegahan dan Penanganan Korban Perdagangan Orang yaitu Pemerintah Daerah wajib melakukan rehabilitasi dan reintegrasi sosial terhadap korban perdagangan orang melalui pemulihan kesehatan fisik dan psikis bagi korban perdagangan orang, reintegrasi sosial korban perdagangan orang ke keluarganya atau lingkungan masyarakatnya, dan pemberdayaan ekonorni dan pendidikan terhadap korban perdagangan orang atau keluarganya yang diawasi dan dikoordinasi oleh sekretaris daerah.

Meskipun Indonesia sudah memiliki Undang-Undang Pemberantasan Tindak Pidana Perdagangan Orang (UU PTPPO), tetap diperlukan keseriusan pemerintah pusat atau pemerintah daerah terkait untuk menanggulangi masalah perdagangan perempuan dan anak karena masalah ini sudah menjadi isu global. Strategi yang dapat dilakukan adalah:

Penegakan Hukum Undang-Undang Pemberantasan Tindak Pidana Perdagangan Orang. Hal ini perlu dilakukan agar konvensi-konvensi internasional yang ada, terutama yang sudah diratifikasi oleh pemerintah Indonesia perlu ditindaklanjuti dengan peraturan yang khusus tentang perdagangan perempuan dan anak atau peraturan yang terintegritas seperti dalam Rancangan KUHPidana. Lalu, dari peraturan tersebut dapat dibuat peraturan daerah, asalkan peraturan daerah (perda) tidak bertentangan dengan konvensi atau undang-undang yang meratifikasi konvensi internasional tersebut.Jangan sampai perda justru mendiskriminasikan dan mengkriminalisasikan perempuan yang sebenarnya merupakan korban (seperti Peraturan Daerah Nomor 8 Tahun 2005 tentang Larangan Pelacuran di Tangerang) (Saraswati, 2015).

Upaya penegak hukum perdagangan perempuan dan anak dalam kaitannya dengan perdagangan perempuan dan anak sangat korup juga perlu dihukum.Di mata hukum jelas mereka telah bersalah, baik dari menerima suap maupun melakukan pemalsuan data dan identitas seseorang. Adanya aparat hukum yang menjadi konsumen dari praktik perdagangan perempuan dan anak (misalnya, pelacuran) juga merupakan salah satu bentuk perilaku yang menjijikan dan samasekali tidak bermoral dari aparat. Karena itu, Perlu keterbukaan dan ketegasan dari pemerintah untuk menindak aparatnya yang benar-benar telah melakukan pelanggaran karena apa yang telah mereka lakukan sebenarnya telah mencoreng nama Indonesia di muka dunia.

Peningkatan Sumber Daya Manusia. Sumber daya manusia yang dimaksud tidak hanya dari aparat pemerintah dan aparat penegak hukum, tetapi juga seluruh masyarakat.Untuk aparat pemerintah dan aparat penegak hukum di samping perlunya meningkatkan integritas moral mereka, diperlukan juga peningkatan profesionalisme kerja.

Strategi peningkatan SDM aparat penegak hukum dapat ditempuh minimal melalui peningkatan pendidikan formal berjangka, melalui kegiatan ilmiah berkala, melalui pengayaan mandiri yang berkaitan dengan bidang tugas, dan menjalin kerja sama dengan institusi perguruan tinggi (Talenta, 2021).

Kemudian, untuk peningkatan sumber daya manusia, khususnya perempuan dan anak/remaja dapat dilakukan melalui pendidikan, baik pendidikan formal maupun non formal; pelatihan keterampilan; dan sebagainya. Upaya pengembangan sumber daya manusia agar memahami masalah perdagangan perempuan dan anak dapat jugga dengan cara melakukan sosialisasi dan kampanye segala produk hukum yang berkaitan dengan perdagangan perempuan dan anak, baik melalui jalur sekolah, aparat pemerintah ditingkat desa atau kelurahan, maupun lembaga swadaya masyarakat (Siallagan \& Siregar, 2017).

Selain itu, keseriusan pemerintah dalam hal pengembangan sumber daya manusia dapat dilihat juga pada kebijakan politiknya terutama melalui dana yang dialokasikan untuk menanganinya. Sebagai contoh, anggaran pembangunan Kota Semarang di bidang yang berkaitan dengan perdagangan perempuan dan anak, yaitu kesehatan; kesejahteraan sosial; serta pemberdayaan perempuan, anak, dan remaja. Pada tahun anggaran 1997 / 1998 hingga 1999 / 2000 masing-masing hanya tercatat 4,09\%; 2,99\%; 3,87; dan 7,43\%. Anggaran tersebut pun masuh harus terbagi lagi melalui aspek ekonomi, pendidikan, agama, dan sosial karena untuk memberdayakan perempuan, anak, dan remaja harus terpadu, tidak bisa terpisah-pisah. Anggaran 
tersebut sangat diskriminatif jika dibandingkan dengan program fisik, misalnya, transportasi dan pemukiman karena untuk periode yang sama jumlahnya adalah $57,23 \% ; 34,75 \% ; 51,80$; dan 60,96 (Silalahi, Dkk, 2019).

Membangun Kerja Sama dan Koordinasi. Pendekatan yang menyeluruh antara agen, seluruh sektor sangat diperlukan untuk menanggulangi masalah perdagangan perempuan dan anak ini. Komunikasi dari bawah untuk mengakomodasi aspirasi atau kehendak sangat diperlukan agar nantinya ada manajemen yag terbuka, jelas, dan akses informasi dapat dijangkau guna pengembangan masyrakat sipil.

Kerja sama dan koordinasi ini harus dilakukan di tingkat nasional, provinsi, lokal bahkan di tingkat internasional dan regional, baik secara bilateral maupun multilateral. Oleh karena itu, untuk membangun kerja sama koordinasi ini sangat dibutuhkan kemauan atau political will dari pemerintah, baik di pusat maupun di daerah, dalam memberantas dan menanggulangi perdagangan perempuan dan anak (Talenta, 2021).

Rencana Aksi Penghapusan Perdagangan (Trafficking) Perempuan dan Anak di Sumatera Utara. Kebijakan Pemerintah Propinsi Sumatera Utara dalam upaya penghapusan perdagangan (trafiking) salah satunya dengan mengeluarkan Perda No. 6 Tahun 2004, tentang Penghapusan Perdagangan (Trafiking) Perempuan dan Anak dan Peraturan Gubernur Sumatera Utara No. 24 Tahun 2005 tentang Rencana Aksi Provinsi Penghapusan Perdagangan (Trafiking) Perempuan dan Anak dan dalam Peraturan Gubsu tersebut terbentuk Gugus Tugas Rencana Aksi Provinsi Penghapusan Perdagangan (Trafiking) Perempuan dan Anak (RAP-P3A), sebagaimana yang diamanatkan Keputusan Presiden No. 88 Tahun 2002 tentang Rencana Aksi Nasional Penghapusan Perdagangan (trafiking) perempuan dan anak (RAN-P3A).

Untuk menghapuskan trafficking (perdagangan) perempuan dan anak ini, Gubernur Sumatera Utara telah mengeluarkan Peraturan Gubernur Sumatera Utara Nomor 24 Tahun 2005 tentang Rencana Aksi Provinsi Penghapusan Perdagangan (Trafficking) Perempuan dan Anak. Visi yang ingin dicapai oleh RAP ini adalah terhapusnya praktik perdagangan (Trafficking) perempuan dan anak di Provinsi Sumatera Utara. Mencapai visi tersebut apa misi yang dilakukan oleh RAP ini; Penegakan hukum dan peraturan perundang-undangan yang jelas, tegas terhadap siapapun, berkenaan dengan perlindungan perempuan dan anak dalam berbagai aspek; Penataan kelembagaan yang efektif dan responsif untuk menangani secara khusus perempuan dan anak tingkat Provinsi dan kabupaten/kota; Pengembangan kapasitas sumber daya manusia yang lebih terpercaya dan professional; Penguatan dan pemberdayaan masyarakat melalui kegiatan ekonomi yang berbasis ekonomi kerakyatan, penyediaan pendidikan yang terjangkau dan mengembangkan hubungan sosial yang harmonis; Peningkatan kesadaran, partisipsi dan kepedulian masyarakat yang hakiki (genuine) terhadap permasalahan perdagangan (trafficking) perempuan dan anak; Penguatan moral melalui peningkatan pendidikan keagamaan mulai dari tingkat keluarga; penguatan hubungan kerjasama dan koordinasi lintas sektoral, Kabupaten/Kota, Provinsi, Nasional dan Internasional untuk terlibat dalam pencegahan dan penanggulangan perdagangan perempuan dan anak (Maidi, Perlindungan Hukum Terhadap Anak Dan Perempuan, 2018)

Maka dalam menghadapi persoalan tersebut perlu adanya Kebijakan untuk Penghapusan Perdagangan (Trafiking) Perempuan dan Anak di Sumatera Utara. Dalam penelitian ini, penulis mengambil objek penelitian Instansi/Lembaga terkait yang merupakan Tim Gugus Tugas Rencana Aksi Provinsi Penghapusan Perdagangan (Trafiking) Perempuan dan Anak (RAP-P3A) di Sumatera Utara, namun demikian sebagai penggiat (Focal Point) dari pihak Pemerintah Provinsi Sumatera Utara adalah Biro Pemberdayaan Perempuan Sekretariat Daerah Provinsi Sumatera Utara.

\section{SIMPULAN}

Faktor-Faktor Penyebab Tindak Pidana Perdagangan Perempuan Dan Anak Di Sumatera Utara: Beberapa faktor yang menyebabkan terjadinya perdagangan anak antara lain sebagai berikut : Kemiskinan; Rendahnya Tingkat Pendidikan; Korban Perceraian Orang Tua; Pengalaman Seksual Dini; Pencari Kerja. Kebijakan Yang Dilakukan Dinas Pemberdayaan Perempuan Dan Anak Di Sumatera Utara Dalam Mencegah Dan Mengatasi Pelaku Perdagangan Orang Terhadap Anak: 
(1)Kebijakan Dalam Mencegah Dan Mengatasi Pelaku Perdagangan Orang : Menjamin peningkatan dan pemajuan atas upaya perlindungan terhadap korban perdagangan (trafficking) perempuan dan anak; Mewujudkan kegiatan-kegiatan baik yang bersifat preventif maupun represif dalam upaya melakukan pencegahan dan penanggulangan atas praktek-praktek perdagangan (trafficking) perempuan dan anak. Mendorong untuk adanya pembentukan dan /atau penyempurnaan peraturan yang berkaitan dengan tindakan perdagangan (trafficking) perempuan dan anak. Untuk menjamin terlaksananya RAN-P3A dibentuk satu gugus tugas nasional sementara untuk menjamin terlaksananya RAN-P3A didaerah dilakukan oleh gugus tugas daerah

Kebijakan Dinas Pemberdayaan Perempuan Dan Anak Di Sumatera Utara Dalam Pemberantasan Tindak Pidana Perdagangan orang: Sebelas tahun pelaksanaan Undang-Undang Nomor 21 Tahun 2007 tentang Pemberantasan Tindak Pidana Perdagangan Orang (UU PTPPO), berbagai kemajuan dicapai dan berbagai tantangan dihadapi. Bahwa bertitik tolak pada sebabsebab timbulnya kejahatan tersebut di atas dapat dicari jalan keluarnya dalam rangka upaya penanggulangannya antara lain: Tahap pertama apa yang disebut pre-entif, tahap kedua yaitu preventif, tahap ketiga yaitu represif. Upaya-upaya pencegahan kejahatan memiliki dampak yang amat berbeda-beda pada tingkat kejahatan dan ketakutan dalam masyarakat. Tak ada pendekatan tunggal bagi pencegahan kejahatan yang telah terbukti dapat diterapkan bagi segala situasi. Memang kebanyakan intervensi tampak berhasil dalam latar-latar terbatas dengan tipe-tipe pelanggar hukum dan masalah kejahatan yang terbatas pula. Ada kebutuhan yang jelas untuk mengidentifikasi teknik pencegahan kejahatan yang tepat dengan situasi yang tepat. Lepas dari ketiadaan dukungan yang konsisten dalam segala evaluasi atas berbagai teknik pencegahan kejahatan, beberapa intervensi yang menjanjikan telah muncul dalam masing-masing dari tiga wilayah pencegahan kejahatan umum. Kebijakan dalam penanggulangan tindak pidana perlindungan orang dilakukan dengan tiga cara yaitu: (a) Pencegahan Primer, (b) Pencegahan Sekunder, (c) Pencegahan Tersier.

\section{DAFTAR PUSTAKA}

Arief, B. N. (2001). Masalah Penegakan Hukum Dan Kebijakan Penanggulangan Kejahatan. Bandung: Citra Aditya Bakti.

Dahlan, S. ( 2017). Penegakan Hukum Dengan Pendekatan Diversi. Yogyakarta: Nusa Media.

Diantha, I. M. (2019). Metodologi Penelitian Hukum Normatif Dalam Justifikasi Teori Hukum,. Jakarta: Prenadamedia Group.

Ediwarman. (2014). Penegakan Hukum Pidana Dalam Prespektif Kriminologi. Yogyakarta: Genta Publishing. Elisabeth, N. (2018). Metode Penelitian Hukum. Bandung: Refika Aditama.

Gede, I. D. (2018). Teori-Teori Hukum, . Malang: Setara Press.

Lab, S. P. (2012). Pencegahan Kejahatan Pendekatan Penerapan (Praktik) Dan Evaluasi, . Jakarta: Anderson Publishing.

Maidi, G. (2018). Perlindungan Hukum Terhadap Anak Dan Perempuan. Bandung: Refika Aditama.

Maidi, G. (2018). Perlindungan Hukum Terhadap Anak Dan Perempuan. Bandung: Refika Aditama.

Marhus, A. (2011). Perdagangan Orang, Dimensi, Instrumen Dan Pengaturannya Di Indonesia, . Bandung: Citra Aditya Bakti.

Nashriana. (2018). Perlindungan Hukum Pidana Bagi Anak Di Indonesia. Jakarta: Raja Grafindo.

Riduwan. (2014). Metode Dan Teknik Menyusun Tesis. Bandung: Alfabeta.

Zulyadi, R. (2020). Kerangka Teori Dalam Penelitian Hukum. Medan: Enam Media.

Rustamaji, M. (2017). Pilar-Pilar Hukum Progresif. Yogyakarta: Thafa Media.

Saraswati, R. (2015). Hukum Perlindungan Anak Di Indonesia. Bandung: P.T Citra Aditya Bakti.

Sinlaeloe, P. (2017). Tindak Pidana Perdagangan Orang. Jakarta: Setara Press.

Talenta, W. J. (2021). Analisis Hukum Terhadap Pemberantasan Tindak Pidana Perdagangan Orang (Human Trafficking) Di Medan (Studi Kasus Di Polrestabes Medan). Medan: Fakultas Hukum Universitas Sumatera Utara.

Wikisource.

(2021,

Februari

15). Https//Id.Wikisource.Org/Wiki/Penghapusan_Perdagangan_Orang_Di_Indonesia_Tahun_2004-2005. Retrieved Februari 15, 2021, from Https//Id.Wikisource.Org: Wikisource

Yasin, M. (2014). Panduan Bantuan Hukum Di Indonesia. Jakarta: Yayasan Obor Indonesia.

Zainuddin. (2009). Metode Penelitian Hukum. Jakarta: Sinar Grafika.

Zulyadi, R. (2020). Perlindungan Hukum Terhadap Anak Sebagai Korban Perdagangan Manusia,. Medan: CV. Pustaka Prima. 
Siallangan, A.F, \& Siregar, T. (2017). Peranan Kantor Pengawasan Dan Pelayanan Bea Dan Cukai Belawan Dalam Penanggulangan Penyelundupan Satwa Dilindungi Jurnal Ilmiah Penegakan Hukum, 4 (1) 2017: 1-7

Silalahi, S.D, Munawir, Z \& Syaputra, M.Y.A, (2019). Perlindungan Hukum Bagi Pekerja Kontrak Yang Mengalami Pemutusan Hubungan Kerja Pada Masa Kontrak (Studi Kasus Putusan Nomor: 82/Pdt.SusPhi/2016/PN. Mdn). JUNCTO, 1(2) 2019: 174-182, 